Journal of Engineering and Applied Sciences 14 (Special Issue 2): 5570-5578, 2019

ISSN: 1816-949X

(C) Medwell Journals, 2019

\title{
Heat Transfer Enhancement using Natural Nanoparticle of Silica ( $\left.\mathrm{SiO}_{2}\right)$
}

\author{
${ }^{1}$ Mohsin J. Jassam, ${ }^{1}$ Zena K. Kadhim and ${ }^{2}$ Muna S. Kassim \\ ${ }^{1}$ Department of Mechanical Engineering, College of Engineering, Wasit University, Kut, Iraq \\ ${ }^{2}$ Department of Mechanical Engineering, College of Engineering, \\ Al Mustansiryah University, Baghdad, Iraq
}

\begin{abstract}
In the represents study, analysis numerically in 3-Dimensional (3D) to study heat transfer characteristics for single tube multi passes cross-flow heat exchanger. The effect of enhanced tubes surface with low integral finned tubes and $\mathrm{Silica}\left(\mathrm{SiO}_{2}\right)$ nanoparticles concentrations with oil (ISO VG-32) as base fluid on the enhancement of heat transfer characteristics and pressure drop. The numerical simulation carried out using of "ANSYS Fluent" package 14.5 to simulate the heat transfer and flow field with oil and nanofluids. Three concentrations of Silica nanoparticles $\left(\mathrm{SiO}_{2}\right)$ have been investigated $0.3,0.5,0.7 \% \mathrm{Vol}$ with oil for flow rate ranged of $2-5 \mathrm{~L} / \mathrm{min}$. The results showed that, using enhanced tube surface with low integral fins lead to a significant increase of heat liberated with maximum enhancement of $71.8 \%$ over smooth tube. The low integral fins increase airside heat transfer coefficient $\left(h_{0}\right)$ of $21.3 \%$ for oil heat exchanger. Also, the results proved that adding $\mathrm{SiO}_{2}$ nanoparticle to base fluid (oil) enhance the inner side $\left(\mathrm{h}_{\mathrm{in}}\right)$ of $6.05 \%$ for Silica $\left(\mathrm{SiO}_{2}\right)$ nanofluids.
\end{abstract}

Key words: $O$ il heat exchangers, low integral finned tubes, Silica nanoparticles $\left(\mathrm{SiO}_{2}\right)$, oil nanofluids, rate, nanofluids

\section{INTRODUCTION}

In many engineering applications, there is an inherent problem, its temperature variations due to heat transfer, absorption of thermal radiation, radioactivity, firing fuel and release of latent heat as fluid vapor condenses or any heat generation sources results in temperature rising. There are encountered example of heat transfer in engineering systems in three modes conduction, convection and radiation and we are interested convection in our study (Mutuku-Njane, 2014).

Cooling system usually used to liberate absorbed heat and one of the most important parts of the system is heat exchangers which are equipment that allow heat to transfer between two or more fluids different temperatures and mostly keeping them from mixing (Cengel, 2002). The amount of heat removed in cooling system increasing with heat transfer coefficients increase. For different technologies heat transfer coefficients are limited, depend upon the cooling fluids used in the process. Developed the cooling system or using different technology, if such is available or used different cooling fluid with the same old technology (Stroder, 2011). Zhang and Fang (2006) compared experimentally the thermal characteristics of the fluid and pressure drop between 2-D (low-integral) and 3-D (petal-shaped) finned tubes. They found that heat transfer coefficients and pressure drops on shell-side for 3-D (petal-shaped) finned tubes are higher than 2-D (low-integral) finned tubes $18-38 \%$ and $25-65 \%$, respectively. Tang et al. (2009) investigated experimentally the effects of fin patterns on heat transfer characteristics. The experimental data showed that the heat transfer rate and friction performance for all fin types is independent on number of tube rows when $\mathrm{N}=6$. Also, at same frontal velocity, slit fin has the highest heat transfer rate and pressure drop while plain fin has the lowest. Zhang et al. (2007) investigated experimentally the heat transfer performances of shell-side and pressure drop for helically baffled single tube heat exchanger with one smooth tube and five petal-shaped fin (pf) tubes. The result show that all (pf(tubes increased heat transfer on the shell side significantly above the smooth tube values. For constant Reynolds number, the best (pf) tube performances gained with the highest fin height and smallest fin pitch. Kadhim et al. (2016) and Zhang et al. (2007) performed an experimental investigation to study the influence of $(\mathrm{MgO})$ nanofluid on the heat transfer characteristics enhancement using low integral finned tube heat exchanger. The results showed that an increment in nanoparticle concentration lead to increase heat transfer rates (Q). Hussein et al. (2013) studied experimentally and numerically the effect of the $\mathrm{TiO}_{2}$

Corresponding Author: Mohsin J. Jassam, Department of Mechanical Engineering, College of Engineering, Wasit University, Kut, Iraq 
nanoparticles concentration of on friction factor and the heat transfer coefficient under turbulent flow. They found that thermal conductivity and viscosity has significant increase when using nanofluids at $(1-2.5 \%)$ volume concentration. Also, the friction factor and heat transfer coefficient increases with increasing in volume concentrations. Nerveless raising Reynolds number increase heat transfer coefficient and decrease the friction factor. Javadi et al. (2013) performed a study to investigate the effect of different shapes of nanoparticle such as cylindrical, bricks, platelets, spherical and blades on the performance of a shell and tube heat exchanger. Thermal conductivity of nanofluids for all shapes increases linearly with volume fraction, the effect of the blade and platelets shapes is almost similar while cylindrical and brick shapes are the highest thermal conductivity. Also, heat transfer coefficient has same effect of the thermal conductivity with maximum (enhancement 2.4\%) at (1) Vol\% for cylindrical shaped as compared with a spherical shape. In the present simulation, we investigate numerically the effect of Silica $\left(\mathrm{SiO}_{2}\right)$ nanoparticles and low integral finned tubes on heat transfer coefficient and pressure drop for two types of oil heat exchanger smooth and integral fins tubes.

The physical model with low integral fins: In the present simulations, the following assumptions are made: single phase of fluids flow (each fluid has single phase), no mixing process. Hot (oil and oil-nanofluid) pass through tubes of heat exchanger and cold air pass over outside tubes through air tunnel shell in cross pattern. The fluid flow and heat transfer processes are turbulent and in steady-state except oil zone conceder laminar zone, constant properties for air, oil and nano-fluid at inlet temperatures, no chemical reaction between nanoparticles and oil. Fluid flow fully developed thermally and hydro dynamically. The heat lost to the environment is neglected the heat exchanger is well-insulated. For convenience the readers, the test section are depicted in Fig. 1. The Reynolds number $(\mathrm{Re})$ and the Nusselt number $(\mathrm{Nu})$ are defined as follows:

$$
\begin{gathered}
\operatorname{Re}_{\mathrm{i}}=\frac{\rho_{\text {oil }} \cdot \mathrm{u}_{\mathrm{oil}} \cdot \mathrm{d}_{\mathrm{i}}}{\mu_{\text {oil }}} \\
\mathrm{Nu}_{\mathrm{i}}=\frac{\mathrm{h}_{\mathrm{i}} \cdot \mathrm{d}_{\mathrm{i}}}{\mathrm{K}_{\mathrm{oil}}} \\
\mathrm{T}_{\mathrm{ave}}=\frac{\mathrm{Tc}_{\mathrm{i}}+\mathrm{Tc}_{0}}{2} \\
\operatorname{Pr}_{\mathrm{a}}=\frac{\mu_{\mathrm{a}} \mathrm{Cp}_{\mathrm{a}}}{\mathrm{K}_{\mathrm{a}}}
\end{gathered}
$$

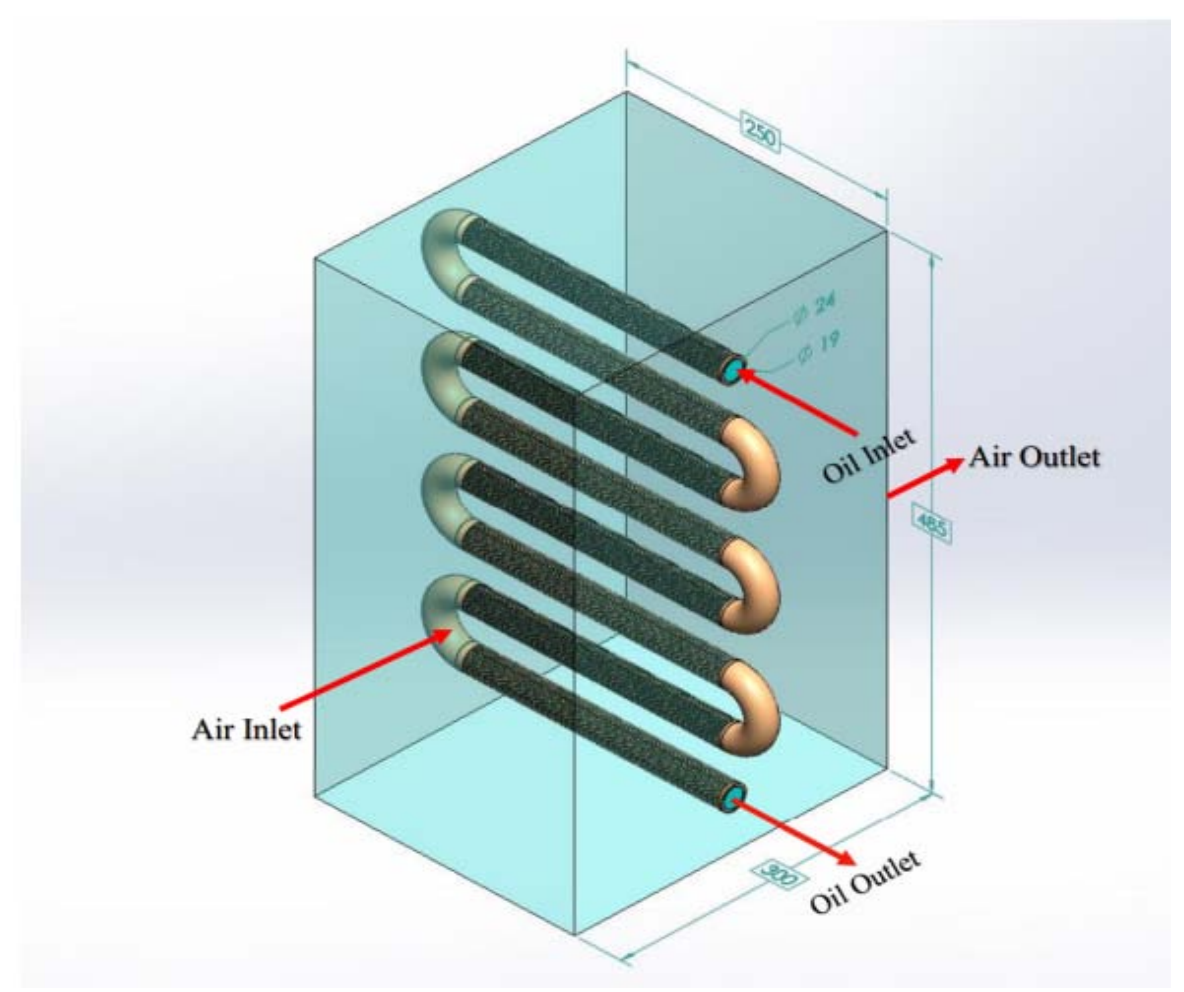

Fig. 1: Geometry of the test section 


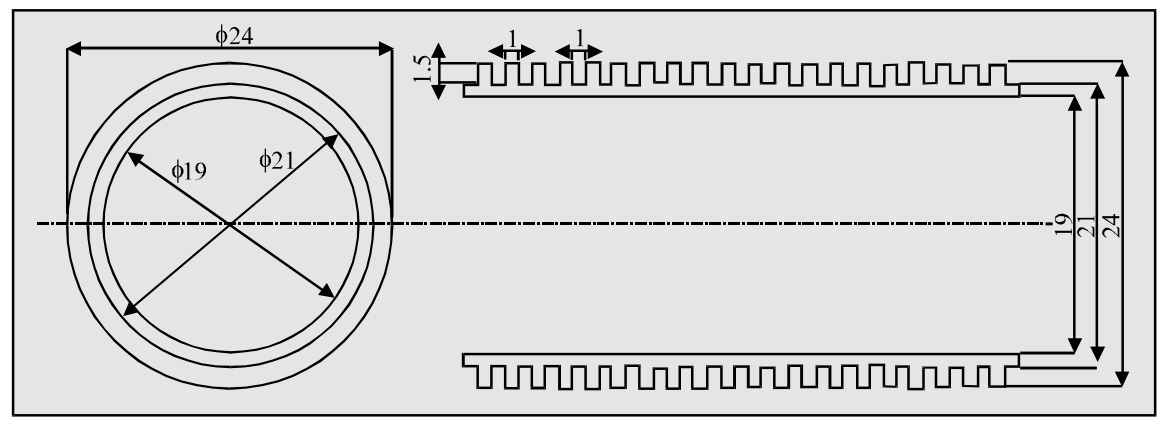

Fig. 2: Schemes of low integral finned tubes

$$
\mathrm{h}_{\mathrm{o}}=\frac{\mathrm{Q}}{\mathrm{A}_{\mathrm{T}}\left(\mathrm{T}_{\mathrm{S}}-\mathrm{T}_{\text {ave }}\right)}
$$

Air is selected as the cooling fluid which is assumed to be incompressible and constant properties at $294.15 \mathrm{~K}$. The thermo physical properties of oil (ISO VG-32) and nanofluid are assumed to be constant at inlet temperature. The thermal conductivity $(\mathrm{k})$ and the specific heat $(\mathrm{Cp})$ of oil are given as $\mathrm{K}=0.13 \mathrm{~W} / \mathrm{m} \mathrm{K}$ and $\mathrm{Cp}=1943 \mathrm{~J} / \mathrm{kg} \mathrm{K}$. The dynamic viscosity $(\mu)$ and the density $(\rho)$ properties are defined as follows (Knezevic and Savic, 2006):

$$
\begin{gathered}
\rho_{\text {oil }}=879 \times\left[1-0.0007 \times\left(\mathrm{T}_{\mathrm{m}}-15\right)\right] \\
\mu_{\text {oil }}=\mathrm{a} \cdot \mathrm{e}^{\frac{\mathrm{b}}{(\mathrm{Tm}-\mathrm{c})}}
\end{gathered}
$$

where, $\mathrm{a}=0.0000736317, \mathrm{~b}=797.7122, \mathrm{c}=177.3562$. All properties of $\mathrm{SiO}_{2}$ nanofluids with three volume concentrations of $0.3,0.5$ and $0.7 \% \mathrm{Vol}$ are calculated from Table 1.

Computational domain: The computational domain for the present investigation was created using solid work premium 2016 software program in 3D form where consists of single passes 8 tubes in horizontal position with one inlet and outlet portion for hot fluid flow. The air duct also has one inlet and outlet portion where the air crossed with the tubes and all the geometry dimensions are listed in Table 2. Figure 2 shows the schemes of low integral finned tubes.

Grid generation and numerical method: One of the most important steps in the pre-processing numerical analysis is mesh generation. The unstructured method, used finite-volume or finite-element scheme to discretize the

\begin{tabular}{|c|c|}
\hline Properties & Equation \\
\hline Density & $\rho_{\mathrm{xf}}=\varphi \rho_{\mathrm{p}}+(1-\varphi) \rho_{\mathrm{w}}$ \\
\hline Viscosity & $\mu_{\mathrm{rf}}=\left(1+\frac{\varnothing}{100}\right)^{113}\left(1+\frac{\mathrm{T}_{\mathrm{xf}}}{70}\right)^{-0.038}\left(1+\frac{\mathrm{d}_{\mathrm{p}}}{170}\right)^{-0.061}$ \\
\hline Thermal conductivity & $\mathrm{K}_{\mathrm{nf}}=\frac{\mathrm{K}_{\mathrm{p}}+2 \mathrm{~K}_{\mathrm{b}}-2\left(\mathrm{~K}_{\mathrm{b}}-\mathrm{K}_{\mathrm{p}}\right) \varphi}{\mathrm{K}_{\mathrm{p}}+2 \mathrm{~K}_{\mathrm{b}}+\left(\mathrm{K}_{\mathrm{b}}-\mathrm{K}_{\mathrm{p}}\right) \varphi}$ \\
\hline Specefic heat & $\mathrm{C}_{\mathrm{nf}}=\frac{(1-\varphi)(\rho \mathrm{C})_{\mathrm{f}}+\varphi(\rho \mathrm{C})_{\mathrm{p}}}{(1-\varphi)_{\mathrm{\rho f}}+\varphi \rho_{\mathrm{p}}}$ \\
\hline Table 2 & lodical models with low integral fins \\
\hline Items & Dimensions (mm) and description \\
\hline $\begin{array}{l}\text { Air duct } \\
\text { w/h/l }\end{array}$ & $250 / 285 / 300$ \\
\hline Smooth tubes & \multirow[b]{2}{*}{$24 / 19$} \\
\hline $\begin{array}{l}\mathrm{d}_{\mathrm{o}} / \mathrm{d}_{\mathrm{i}} \\
\text { Integral finned tubes }\end{array}$ & \\
\hline $\mathrm{d}_{\mathrm{of}} / \mathrm{d}_{\mathrm{r}} / \mathrm{d}_{\mathrm{i}}$ & $24 / 21 / 19$ \\
\hline Effective length & 250 \\
\hline Tubes pitch & 55 \\
\hline Material & Cupper \\
\hline
\end{tabular}
integral form of governing equations, so as a result it's adopt in present study (Kadhim et al., 2016).
The mesh of 3D system was generated using ANSYS package based on the 3D geometry created in a solid work premium 2016 software. The grid was generated with tetrahedral elements and the mesh independence tests are carried out for every model. For example, three grid type systems with 1, 431, 301, 1, 735, 159 and 1, 973, 415 are established to calculate smooth tube model and difference in heat transfer coefficient between the of last tow grid are around $1.5 \%$. So, considering the solution accuracy and computational time cost the second grid model is adopted. The cell number for low integral finned tube model, high quality and very fine mesh at the boundaries with $10,227,072$ total cells number and maximum aspect ratio $=2.11794 \mathrm{e}+01$.

To compute the flow and heat transfer domain the commercial code Fluent 14.5 is used. The present numerical method is the same used in thesis (Kadhim et al., 2016). The computation is performed in parallel processing on tow $\mathrm{hp}$ workstation laptop with 
(a)

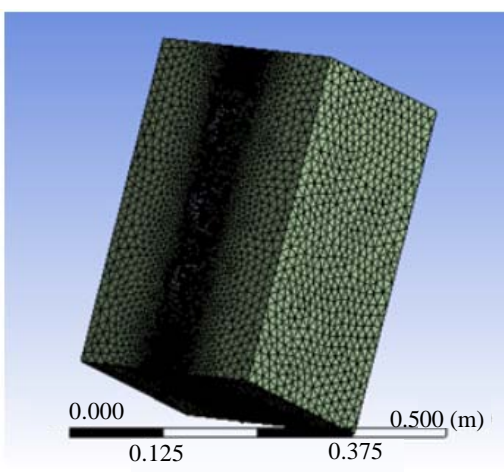

(b)

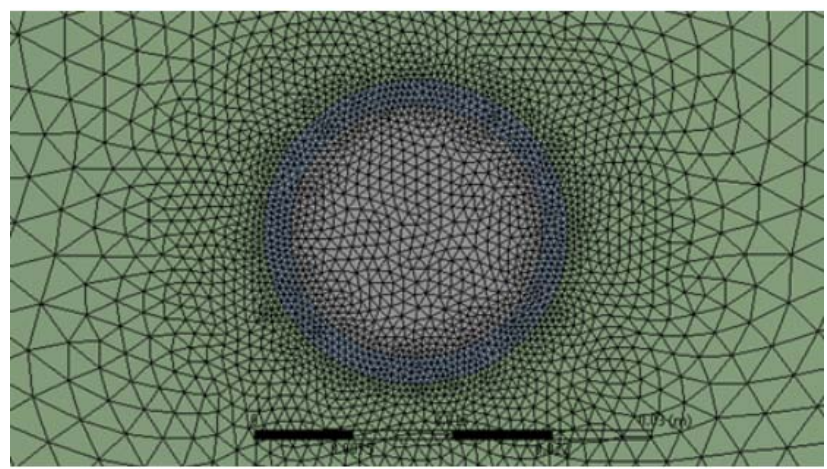

Fig. 3: a, b) The mesh

Core i7, $16 \mathrm{~GB}$ memory and $3.4 \mathrm{GH}$ turbo speed by using Fluent 14.5 each case tacks $5 \mathrm{~h}$ for each 300 iterations.

\section{Numerical simulations}

Governing equations and boundary conditions: The fundamental equations continuity, momentum and energy are the most uses in CFD problems solution also the boundary conditions for smooth tubes model are the same of low integral finned tubes (Zhang et al., 2012).

Continuity equation:

$$
\frac{\partial\left(\rho u_{i}\right)}{\partial x_{i}}=0
$$

Momentum equations:

$$
\frac{\partial}{\partial x_{i}}\left(\rho u_{i} u_{j}\right)=\frac{\partial p}{\partial x_{i}}+\frac{\partial}{\partial x_{j}} \cdot\left[\mu\left(\frac{\partial x_{i}}{\partial x_{j}}+\frac{\partial u_{j}}{\partial x_{i}}\right)\right]
$$

Energy equation:

$$
\frac{\partial}{\partial x_{j}}\left(\rho u_{j} C p T-k \frac{\partial T}{\partial x_{j}}\right)=0
$$

Solve the above governing equations aligned with boundary conditions. The standard pressure-base with K-epsilon (Eq. 2) turbulent model with oil and $\mathrm{SiO}_{2}$ nanofluid checked as laminar zone. The pressure-velocity coupling is treated with SIMPLE algorithm and second order upwind discretization schemes for energy and momentum equations in the present model. Additionally, the convergence criteria, (0.0001) for velocity and continuity and (1e-06) for energy. Non-uniform structured mesh (tetrahedral) was generated using ANSYS 14.5 with very fine grids in the region near the tube wall. Figure 3 shows the mesh of the tube fitted within Air tunnel. The inlet boundary conditions of cooling fluid, the air inlet velocity set to $1,1.8,2.6$ and $3.4 \mathrm{~m} / \mathrm{sec}$ at room temperature $294.15 \mathrm{~K}$ and for hot fluid, oil or $\mathrm{SiO}_{2}$ nanofluid, the inlet mass flow rate set to $2,3,4$ and 5 $\mathrm{L} / \mathrm{min}$, each flow rate is set at constant temperature 323.15 , $333.15,343.15$ and $353.15^{\circ} \mathrm{C}$. The outlet boundary conditions of hot, oil or $\mathrm{SiO}_{2}$ nanofluid and cold fluid, air are assumed to be equal to atmospheric pressure. Wall boundary condition for shear condition no slip specified at the wall and thermal conditions, coupled heat transfer condition at wall interface between solid and fluid or no heat flux at insulated wall.

\section{RESULTS AND DISCUSSION}

Heat liberated from the hot fluid (oil and $\mathrm{SiO}_{2}$ nanofluids) flowing through the tubes to the cold fluid (Air) flows inside the air tunnel a cross heat exchanger is analysis using ANSYS Fluent 14.5.

\section{Flow structure}

Velocity field: Figure 4 shows cross section of predicted velocity contour of oil smooth and low integral finned tubes heat exchanger with. This figure shows that the oil velocity are constant due to stability mass flow rate and constant cross section area of flow. Also, the figure shows that the air velocity are constant before the tested tubes and then increase rapidly near the tested tubes where maximum air velocity occur at the chocking area between the tubes. Also, it's the air velocity at the chocking area for smooth tube higher than integral tube because of the chocking area between integral tube larger than smooth tube also due to turbulence and eddies due to fins reduce the air velocity. After passing the air pass through tubes the air velocity start to reduce. Figure 5 demonstrate the turbulence region and eddies formed behind the tubes where the integral finned tubes generate higher turbulence than smooth tubes. Also, clarify the throttling area between tubes. 


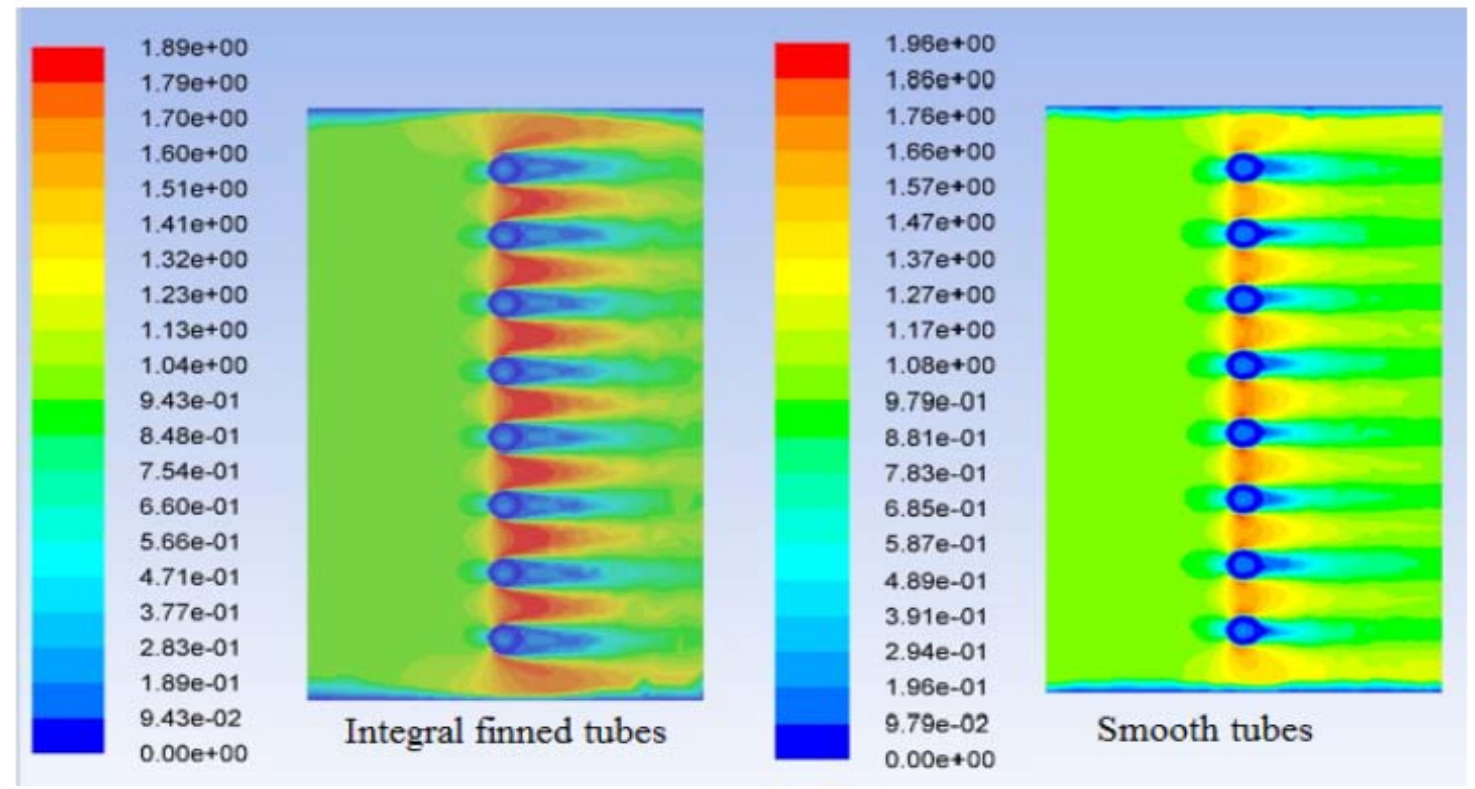

Fig. 4: The velocity contour for smooth and low integral finned tubes heat exchanger

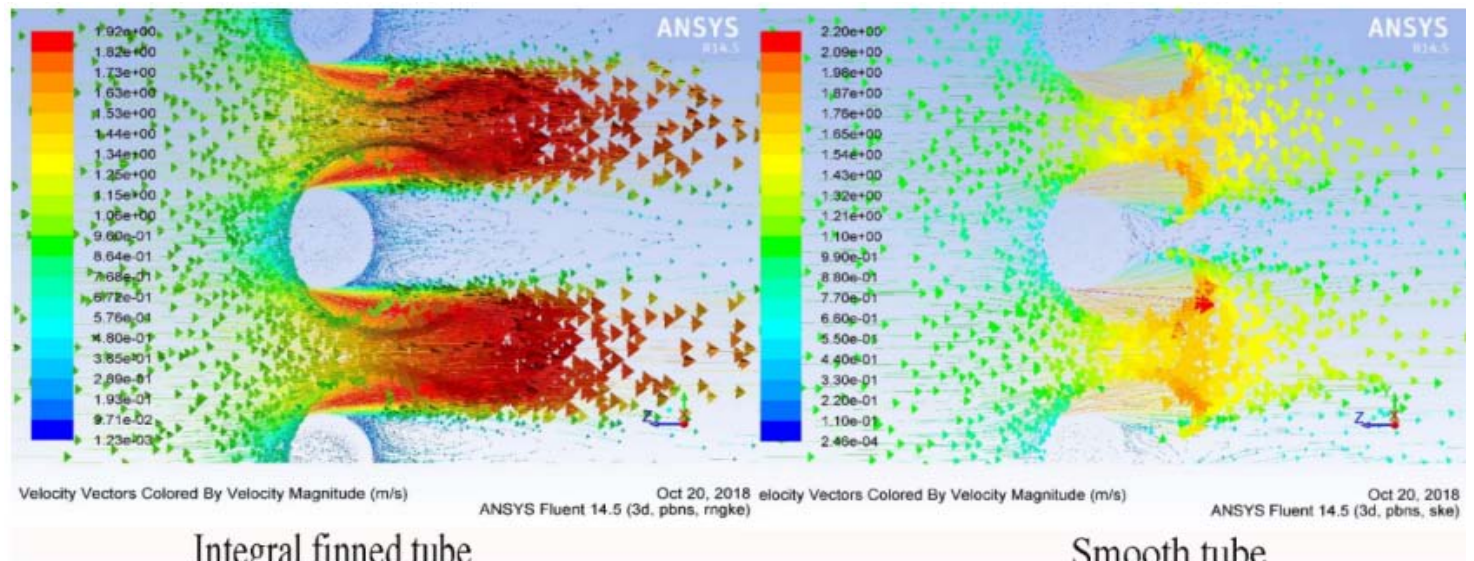

Fig. 5: The velocity vector for smooth and low integral finned tubes heat exchanger

Temperature contours: The temperature distributions through test section are showed in 3D in Fig. 6. Figure 7 demonstrated longitudinal and cross section of temperature contours for oil heat exchanger. Certainly, the temperature difference increase along with tube for both smooth and integral find tube. Nerveless, the temperature difference for finned tube greater than smooth tube heat exchanger for all cases of oil and $\mathrm{SiO}_{2}$ nanofluid.

Heat liberated: The effect of inlet oil temperature and air velocity at different oil flow rates have been investigated. We demonstrate that at a certain flow rate, the heat liberated increase significantly with rising oil inlet temperature as shows in Fig. 8. Where the increase inlet oil temperature lead to increase the temperature difference between tubes surface temperature of heat exchanger and air temperature. This phenomenon is general for smooth and integral finned tubes heat exchanger. Nevertheless, at the same conditions the heat liberate of low integral finned tubes heat exchanger greater than smooth tubes heat exchanger as a result of increase the surface area and turbulence generated due to fins.

Also, the results prove that the heat liberated increase with air velocity rise for smooth and low finned tubs heat exchanger as results of increase Re which introduced higher turbulence. Nevertheless, at the same conditions 
J. Eng. Applied Sci., 14 (Special Issue 2): 5570-5578, 2019

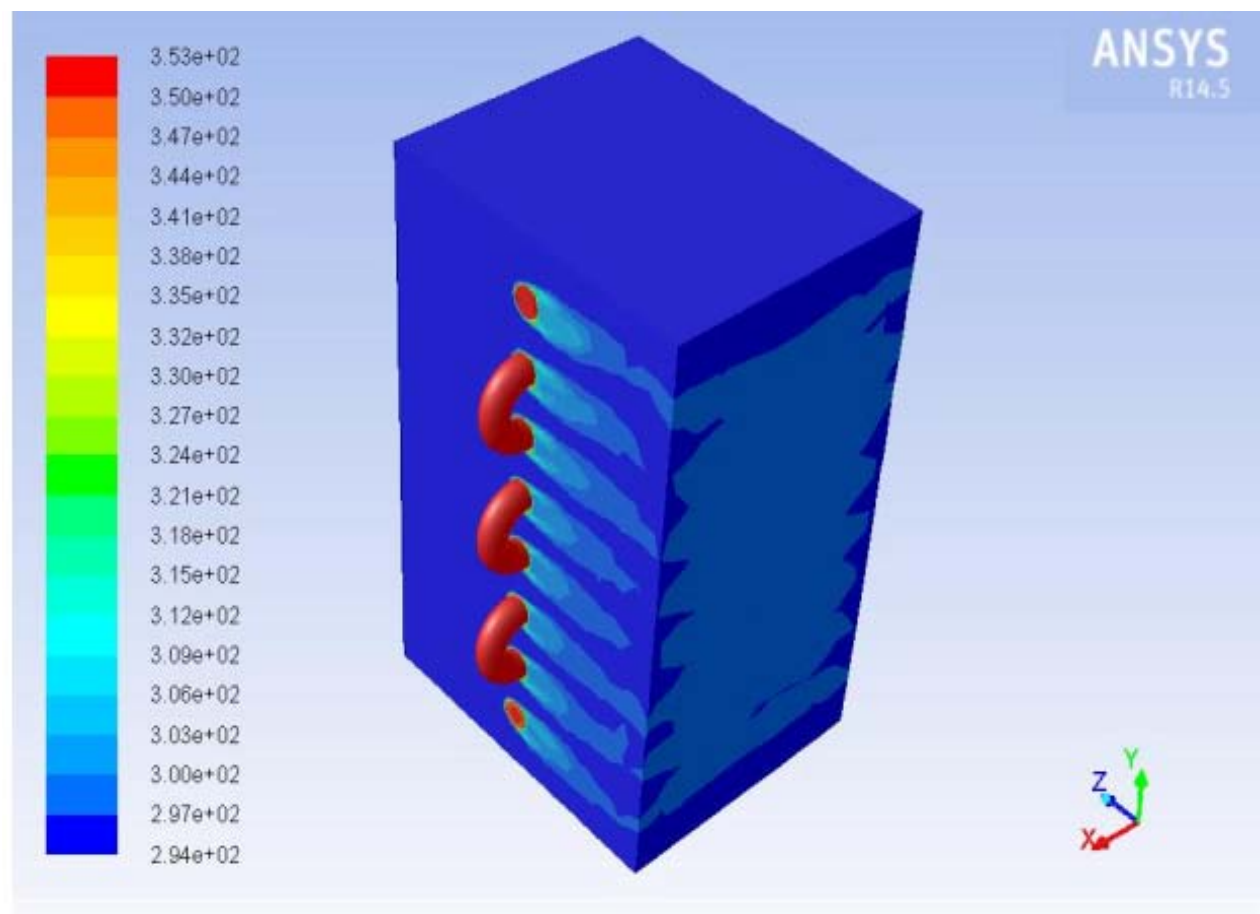

Contours of Static Temperature (k)

Oct 19, 2018

ANSYS Fluent 14.5 (3d, pbns, mgke)

Fig. 6: Three diamensional view

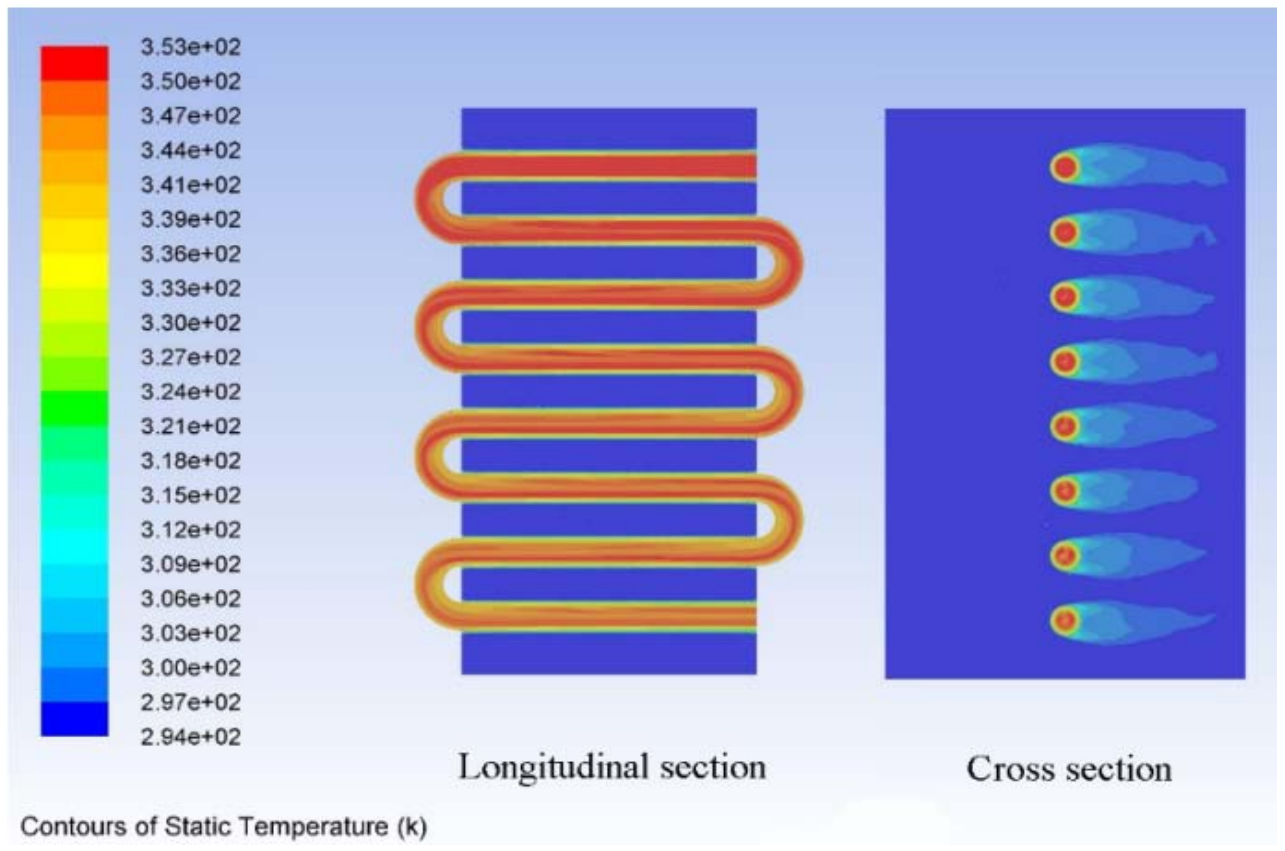

Fig. 7: The temperature contours of oil heat exchanger

the heat liberate of low integral finned tubes heat exchanger greater than smooth tubes heat exchanger as a result of increase the surface area and turbulence generated due to fins as showed in Fig. 9. The heat liberated form low integral finned tubes greater than smooth tubes heat exchanger by $71.8 \%$ 


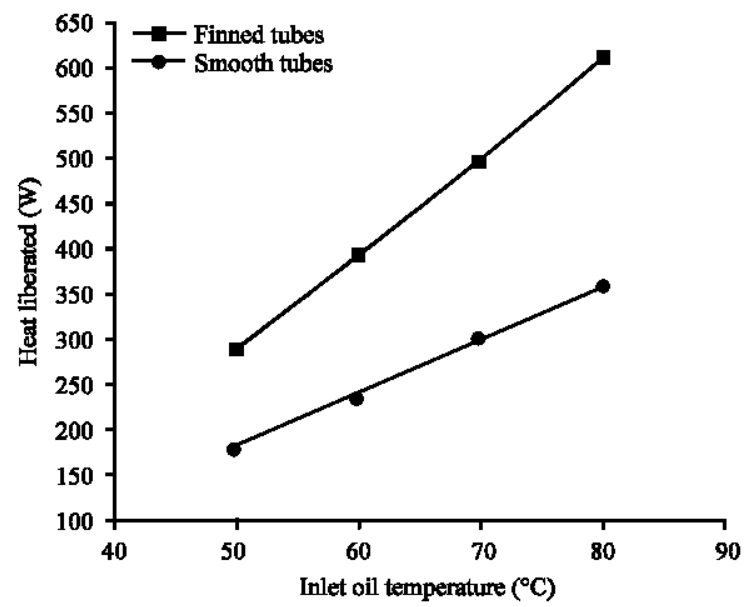

Fig. 8: Variation of oil heat liberated rate with inlet oil temperature for smooth and low integral finned tubes

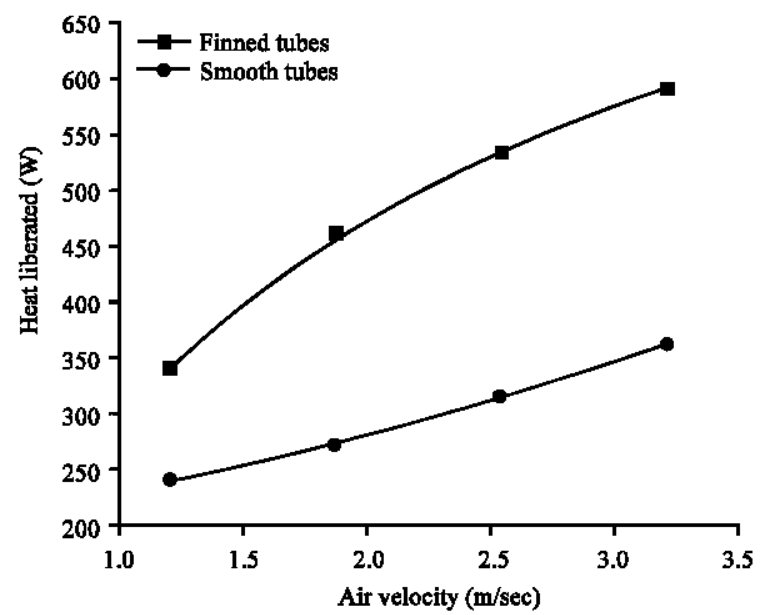

Fig. 9: Variation of oil heat liberated rate with air velocities for smooth and low integral finned tubes

at the optimum conditions (inlet temperature $=0.80^{\circ} \mathrm{C}$, air velocity, $3.4 \mathrm{~m} / \mathrm{sec}$ and oil or water flow rate, $5 \mathrm{~L} / \mathrm{min})$.

Air side heat transfer coefficient $\left(h_{0}\right)$ : Figure 10 depict the effect of Reynolds number variation in air side on heat transfer coefficient $\left(h_{0}\right)$ at a certain oil mass flow and inlet temperature for smooth and low finned tubes. The results demonstrate air velocity has significant effect on air side heat transfer coefficient. Where raising air velocity result an upsurge outer heat transfer coefficient $\left(h_{0}\right)$ because of increasing the turbulence generated by the air velocity augment. Additionally, heat transfer coefficient of the integral low finned tube is greater than smooth tubes duo to the fins which increase the heat liberated

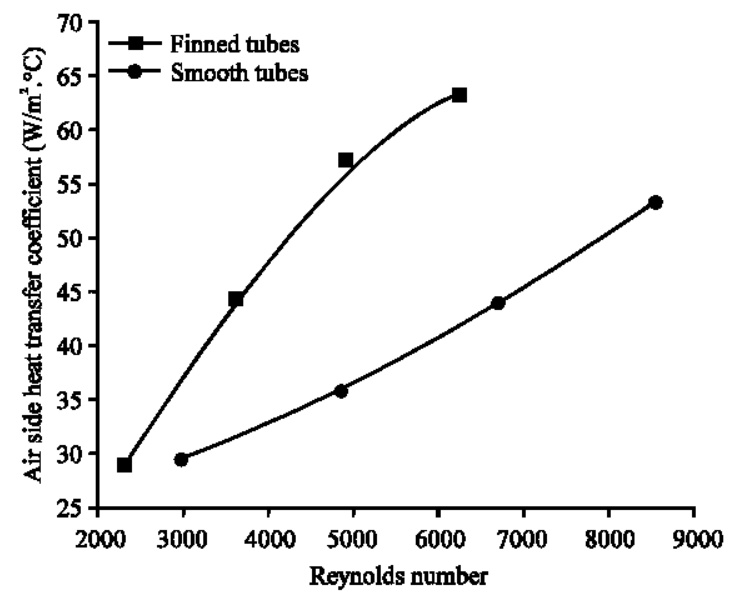

Fig. 10: Variation of air side heat transfer coefficient with Reynolds number for smooth and low integral finned tube

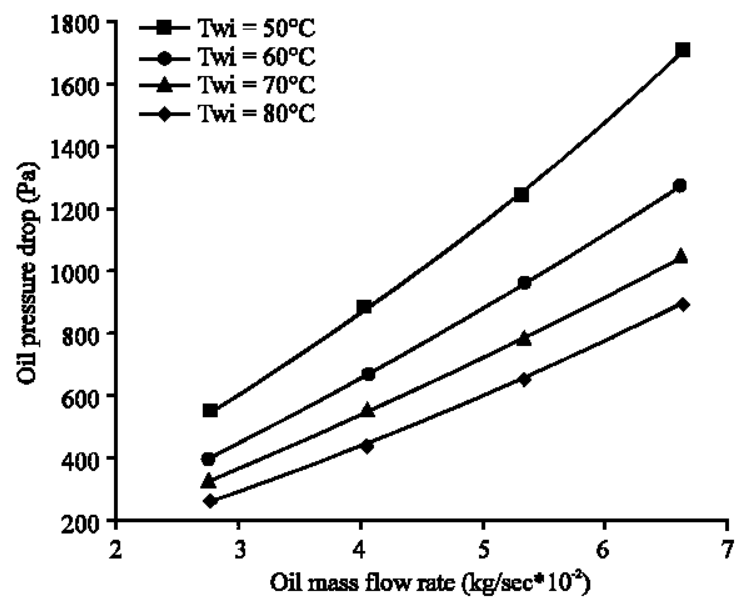

Fig. 11: Variation of oil side pressure drop with mass flow rate at different inlet temperatures

surface area also generate higher turbulence and vortices. The maximum enhancement of air heat transfer coefficient $\left(h_{0}\right)$ of 76.1 and $124.5 \%$ when increase the air velocity by 3.4 times for smooth and finned tube heat exchanger. Where air heat transfer coefficient $\left(h_{0}\right)$ for finned tubes greater than smooth tubes by $21.3 \%$.

Pressure drop: Figure 11 showed the effect of oil mass flow rate on oil side pressure drop. Where raising oil flow rate of $2-5 \mathrm{~L} / \mathrm{min}$ increase the pressure drop significantly due to increase the friction force and turbulence generated and thus, increase the impact between the fluid particles. The result shows that the percentage of increase of pressure drop of $235.3 \%$ for oil a finned tubes heat exchanger. 


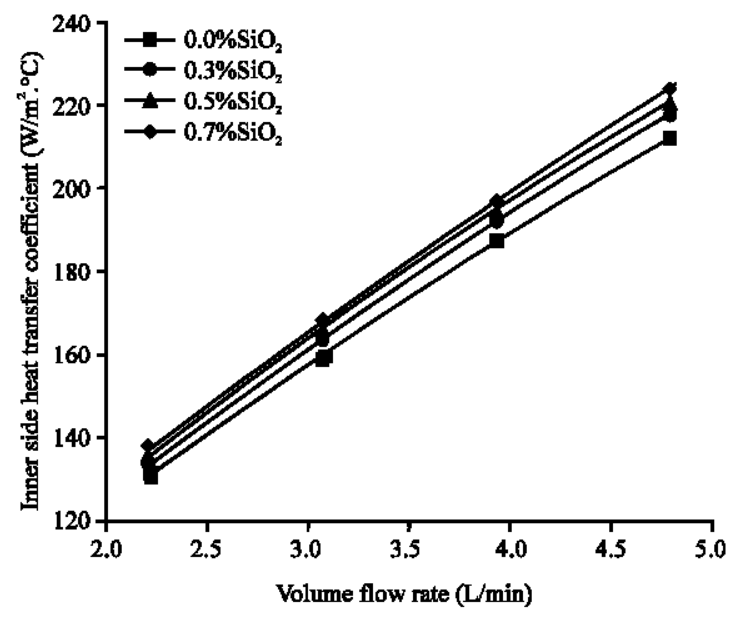

Fig. 12: Variation of inner side heat transfer coefficient for oil and different concentration of Silica $\left(\mathrm{SiO}_{2}\right)$ nanofluids

Also, Fig. 12 revealed the influence of oil inlet temperature on inner side pressure drop. Where rising the inlet temperature decrease the pressure drop due to reduce the viscosity and density of the fluids and therefore, reduce the drag force.

Oil side heat transfer coefficient: Figure 13 depict the inner side heat transfer coefficient $\left(h_{i}\right)$ variation of silica nanofluid at different volume flow rate and volume concentration of nanoparticles for integral finned tubes heat exchanger. The oil side heat transfer coefficient $\left(h_{i}\right)$ for enhanced tubes surface greater than smooth tube heat exchanger of $20.4 \%$. Figure 12 demonstrate that increasing both volume flow rate of $\mathrm{SiO}_{2}$ nanofluids and volume concentrations of nanoparticles in base fluid, oil (ISO VG-32) increases the heat transfer coefficient. At optimum conditions, raising volume flow rate of $\mathrm{SiO}_{2}$ nanofluids generate greater turbulence as well as existing nanoparticles in oil enhance the thermal conductivity. Also, raising Silica $\left(\mathrm{SiO}_{2}\right)$ the nanoparticles concentration of $0.3-0.7 \% \mathrm{Vol}$ increasing thermal conductivity and that decreases the thickness of thermal boundary layer. This is because of inherent random motion of particles near the wall and movement of them to the center of the tube where maximum enhancement 6.3 at $0.7 \% \mathrm{Vol}$ concentrations of Silica $\left(\mathrm{SiO}_{2}\right)$.

\section{CONCLUSION}

In the present 3-D numerical simulation of oil heat exchanger, we have been focused on the benefits gained of using enhanced tubes surface with low integral fins and $\mathrm{SiO}_{2} /$ oil nanofluids in single tube multy pass cross flow heat exchanger. Where the effect of oil inlet temperature, mass flow rate, $\mathrm{SiO}_{2}$ nanoparticles volume concentration and air velocity on heat transfer coefficient and pressure drop was study. The result revealed that, the heat liberated of enhanced tube surface greater than smooth tubes and increase significantly with raising inlet temperature and air velocity with maximum enhancement of $71.8 \%$. The air side heat transfer coefficient $\left(h_{0}\right)$ enhanced of $21.3 \%$ with the increase of inlet air velocity 3.4 times. Also, the oil side heat transfer coefficient $\left(h_{i}\right)$ of enhanced tube surface greater than smooth tube by $20.4 \%$ where increase with increasing of oil mass flow rate. Additionally, increasing the volume concentrations of Silica $\left(\mathrm{SiO}_{2}\right)$ nanoparticles of $0-0.7 \%$ Vol. enhance innerside heat transfer coefficient $\left(h_{i}\right)$ of $6.3 \%$.

\section{NOMENCLATURE}

Symbol description (units)
$A=\operatorname{Area}\left(\mathrm{m}^{2}\right)$
$\mathrm{A}_{\mathrm{c}}=$ Cross sectional area $\left(\mathrm{m}^{2}\right)$
$A_{i}=$ Inner surface area of the tube $\left(\mathrm{m}^{2}\right)$
$A_{0}=$ Outer surface area of the tube $\left(\mathrm{m}^{2}\right)$
$\mathrm{C}_{\mathrm{p}}=$ Specific heat of the fluid $\left(\mathrm{J} / \mathrm{kg} \cdot{ }^{\circ} \mathrm{C}\right)$
$\mathrm{d}=$ Diameter $(\mathrm{m})$
$\mathrm{d}_{\mathrm{h}}=$ Hydraulic diameter $(\mathrm{m})$
$\mathrm{d}_{\mathrm{of}}=$ Outer diameter of finned tube $(\mathrm{m})$
$\mathrm{d}_{\mathrm{r}}=$ Root diameter of finned tube $(\mathrm{m})$
$\mathrm{f}=$ Friction factor $(-)$
$\mathrm{h}_{\mathrm{i}}=$ Inner side heat transfer coefficient $\left(\mathrm{W} / \mathrm{m}^{2} .{ }^{\circ} \mathrm{C}\right)$
$\mathrm{h}_{0}=$ Air side heat transfer coefficient $\left(\mathrm{W} / \mathrm{m} 2 .{ }^{\circ} \mathrm{C}\right)$
$\mathrm{K}=$ Thermal conductivity $\left(\mathrm{W} / \mathrm{m} .{ }^{\circ} \mathrm{C}\right)$
$\mathrm{L}=$ Tube length (summation of straight tubes) (m)
$\dot{\mathrm{m}}=$ Mass flow rate $(\mathrm{kg} / \mathrm{sec})$
$\mathrm{Nu}=$ Nusselt's number (convection heat transfer/conduction heat transfer) (-)
$\operatorname{Pr}=$ Prandtl number (molecular diffusivity of momentum/molecular diffusivity of heat) (-)
$\mathrm{Q}=$ Heat liberated rate rate $(\mathrm{W})$
$\operatorname{Re}=$ Reynolds number (inertia force/viscous force) (-)
$\mathrm{T}=$ Temperature $\left({ }^{\circ} \mathrm{C}\right)$
$\mathrm{T}_{\mathrm{s}}=$ Average surface temperature of test tube $\left({ }^{\circ} \mathrm{C}\right)$
$\mathrm{u}=$ Fluid velocity (oil, water and nanofuid) $(\mathrm{m} / \mathrm{sec}$ )
$\mathrm{V}_{\mathrm{a}}=$ Air velocity
$\mathrm{W}=$ Width of the duct $(\mathrm{m})$
$\mathrm{H}=$ Height of the duct (m)
$\rho=$ Fluid density $\left(\mathrm{kg} / \mathrm{m}^{3}\right)$
$\mu=$ Dynamic viscosity $(\mathrm{kg} / \mathrm{m} \cdot \mathrm{sec})$
$\varphi=$ Volume concentration percentage
$\mathrm{P} \Delta=$ Pressure drop $(\mathrm{Pa})$
$\Delta \mathrm{T}=$ Temperature difference $\left({ }^{\circ} \mathrm{C}\right)$ 
$\mathrm{i} \quad=$ Inside inlet conditions

$0 \quad=$ Outside, Outlet conditions

$\mathrm{nf}=$ Nanofluid

$\mathrm{a}=$ Air

ave $=$ Average value

\section{REFERENCES}

Azmi, W.H., K.V. Sharma, P.K. Sarma, R. Mamat and S. Anuar et al., 2014. Numerical validation of experimental heat transfer coefficient with $\mathrm{SiO}_{2}$ nanofluid flowing in a tube with twisted tape inserts. Appl. Therm. Eng., 73: 296-306.

Cengel, Y.A., 2002. Heat Transfer: A Practical Approach. 2nd Edn., McGraw-Hill Education, New York, USA., ISBN-13:978-0072458930, Pages: 896.

Hussein, A.M., K.V. Sharma, R.A. Bakar and K. Kadirgama, 2013. The effect of cross sectional area of tube on friction factor and heat transfer nanofluid turbulent flow. Intl. Commun. Heat Mass Transfer, 47: 49-55.

Javadi, F.S., S. Sadeghipour, R. Saidur, G. BoroumandJazi, B. Rahmati, M.M. Elias and M.R. Sohel, 2013. The effects of nanofluid on thermophysical properties and heat transfer characteristics of a plate heat exchanger. Int. Commun. Heat Mass Transfer, 44: 58-63.

Kadhim, Z.K., M.S. Kassim and A.Y.A. Hassan, 2016. Effect of (MGO) nanofluid on heat transfer characteristics for integral finned tube heat exchanger. Int. J. Mech. Eng. Technol., 7: 11-24.
Knezevic, D. and V. Savic, 2006. Mathematical modeling of changing of dynamic viscosity, as a function of temperature and pressure, of mineral oils for hydraulic systems. Mech. Eng., 4: 27-34.

Mutuku-Njane, W.N., 2014. Analysis of hydromagnetic boundary layer flow and heat transfer of nanofluids. Ph.D Thesis, Cape Peninsula University of Technology, Cape Town, South Africa.

Stroder, S., 2011. Convective heat transfer with nanofluids. Master Thesis, Energy Technology Department, Royal Institute of Technology, Stockholm, Sweden.

Tang, L.H., Z. Min, G.N. Xie and Q.W. Wang, 2009. Fin pattern effects on air-side heat transfer and friction characteristics of fin-and-tube heat exchangers with large number of large-diameter tube rows. Heat Transfer Eng., 30: 171-180.

Zhang, X., Z. Liu and W. Liu, 2012. Numerical studies on heat transfer and flow characteristics for laminar flow in a tube with multiple regularly spaced twisted tapes. Intl. J. Therm. Sci., 58: 157-167.

Zhang, Z. and X. Fang, 2006. Comparison of heat transfer and pressure drop for the helically baffled heat exchanger combined with three-dimensional and two-dimensional finned tubes. Heat Transfer Eng., 27: $17-22$.

Zhang, Z., Z. Yu and X. Fang, 2007. An experimental heat transfer study for helically flowing outside petal-shaped finned tubes with different geometrical parameters. Appl. Therm. Eng., 27: 268-272. 